\title{
DARING LECTURE CULTURE: PREFERENCE OF ISLAMIC EDUCATION LEARNING AT COLLEGE DURING AND POST COVID-19 OUTBREAK
}

\author{
Nuraliah Ali \\ Universitas Palangka Raya, Indonesia \\ Email: nuraliahali@law.upr.ac.id
}

\author{
Adilham \\ Politeknik Pertanian Negeri Pangkep, Indonesia \\ Email: adilhamek@gmail.com
}

\begin{abstract}
Concerning the pandemic COVID-19, which was designated as a national disaster, the Ministry of Education and Culture issued a policy that every unit of education should transform face-to-eye learning into distance learning. In the context of Islamic education in college, the policy forced all actors of Islamic education to change the culture or customs of learning into distance-learning or online. This qualitative descriptive research seeks to describe systematically, scientifically, and factual descriptions, challenges, and strategies of ICT optimization/ utilization on each component of the lecture as a learning solution during and after the COVID-19 pandemic. The data collection methods used in this study are document content with data analysis using latent content analysis. The challenges faced in building a culture of online lectures are unqualified infrastructure, different socio-economic factors, the unpreparedness of human resources (resistance to change, attitudes and confidence, minimal digital skills), and resource accessibility. Constructing the culture of online lectures on Islamic education needs to pay attention to several aspects such as expected outcomes, required financing, responsibilities, resource requirements, and evaluation.
\end{abstract}

Keywords: lecture culture, daring, e-learning, Covid-19

\begin{abstract}
Abstrak
Berkaitan dengan Pandemi COVID-19 yang ditetapkan sebagai bencana nasional, Kementerian Pendidikan dan Kebudayaan mengeluarkan kebijakan bahwa setiap satuan pendidikan harus mentransformasikan pembelajaran tatap muka menjadi pembelajaran jarak jauh. Dalam konteks pendidikan Islam di perguruan tinggi, Kebijakan tersebut memaksa semua pelaku pendidikan Islam untuk merubah culture atau kebiasan pembelajaran menjadi pembelajaran jarak jauh atau daring. Penelitian deskriptif kualitatif ini, berusaha untuk menggambarkan secara sistematis, ilmiah, dan faktual mengenai gambaran, tantangan dan strategi pembelajaran daring/ online berbasis ICT pada setiap komponen perkuliahan sebagai solusi pembelajaran selama dan pasca pandemi COVID-19. Metode pengumpulan data yang digunakan dalam studi ini adalah konten dokumen dengan analisis data menggunakan analisis konten laten. Adapun tantangan yang dihadapi dalam
\end{abstract}


Nuraliah Ali \& Adilham: Daring Lecture Culture: Preference of Islamic Education Learning at College during and post Covid-19 Outbreak

\begin{abstract}
membangun budaya perkuliahan daring adalah infrastruktur yang belum mumpuni, faktor sosial-ekonomi yang berbeda, ketidaksiapan sumberdaya manusia (resistansi terhadap perubahan, sikap dan kepercayaan diri, keterampilan digital yang minim), dan aksebilitas sumberdaya. Mengkonstruksi budaya perkuliahan daring pada pendidikan Islam perlu memperhatikan beberapa aspek seperti hasil yang diharapkan, pembiayaan yang diperlukan, tanggung jawab, kebutuhan sumber daya, dan evaluasi.
\end{abstract}

Kata Kunci: budaya perkuliahan, daring, e-learning, Covid-19

\title{
A. Introduction
}

Coronavirus Novel Disease 2019 (COVID-19) that started in China at the end of 2019 spread very quickly in some countries. COVID-19, which caused an outbreak of acute infectious pneumonia, ${ }^{1}$ put hard pressure on various aspects of life, ranging from government authorities, medical and healthcare providers, and the general public. ${ }^{2}$ The spread of continuous and increasing COVID-19 viruses led to the Government taking policy measures for physical and social distancing with the slogan stay at home, work from home, a study from home, and worship from home. In the context of education, these policy forces the educational world to change culture and learning habits that usually have to be present and be in a classroom or building room, becoming online learning/daring with its various characteristics. Educators are required to build a lecture culture-based online/daring.

The cultural lecture is a sub-component of an academic culture that has a strategic value in encouraging the development of an appointment in college. ${ }^{3}$ Colleges that have a conducive academic culture will influence the colleges' performance, productivity levels, and achievement. Students who are in a conducive college culture will try to improve their performance and simultaneously improve their image. Therefore, repent for the lecturer to build coursework conducive and compatible with the demands of the times. The effort to construct a culture of lectures is not easy. The

\footnotetext{
${ }^{1}$ Y. Bao, Y. Sun, S. Meng, J. Shi, L. Lu, "2019-nCoV Epidemic: Address Mental Health Care to Empower Society," Lancet 395 (10224), e37-e38, (London: England, 2020), 1

${ }^{2}$ X. Pan, D.M. Ojcius, T. Gao, Z. Li, C. Pan, "Lessons Learned from the 2019-nCoV Epidemic on Prevention of Future Infectious Diseases," Microbes and Infection/Institut Pasteur 22 (2) 2020: 86-91. See too, Q. Chen, M. Liang, Y. Li, J. Guo, D. Fei, L. Wang, L. He, C. Sheng, Y. Cai, X. Li, J. Wang, Z. Zhang, "Mental Health Care for Medical Staff in China during the COVID-19 Outbreak," The Lancet Psychiatry, 2020a.

${ }^{3}$ Muhammad Ridlo Zarkasyi, "Membangun Budaya Akademik pada Perguruan Tinggi Pesantren," Al Tijarah, Vol. 3, No. 2 (2017): 65-96
} 
analogy of building a lecture culture is the same as building a sturdy building, requiring careful planning, cautious implementation, continuous evaluation, and time to match the level of complexity of the draft. These values, habits, and cultures are further socialized and internalized continually to be attached to the subject, object, and all components of the lecture system. The culture that has been successfully socialized in the members will bring about a strong culture, which is the culture in which the core values are firmly held and highly endowed together. ${ }^{4}$

The governance of the lecture of Islamic Studies in colleges, especially in public colleges in Indonesia, is required to respond to the challenges in education. One of the challenges facing education during and post Covid-19 pandemic or new normal pandemic is the demand for the utilization and optimization of the use of information and communication technology (ICT) in academic activities. Lecturers are required to be able to innovate learning in every lecture. The innovation of lectures is conducted on every aspect of the lecture which includes planning, process, and evaluation. Reigeluth means that educational innovations in learning methods include a formulation of teaching materials, delivery strategies, and management of activities concerning the objectives, barriers, and characteristics of learners. ${ }^{5}$

The discussion relating to Covid-19 is an interesting topic to be studied today. It can be seen from the many research and studies about Covid-19 in various disciplines aspects, namely health, economics, social politics, and education. It is based on the insisting of situations and conditions that force people to know, recognize, and adapt to the current conditions. Previous studies have similarly with this study, that describes Covid-19 subject and the utilization of ICT in learning. The difference lies in the exposure of ICT internalization in every component aspect of the lecture, such as planning, process, and evaluation in Islamic Religious Education (PAI).

Therefore, the research "Daring Lecture Culture: Preference Learning on Islamic Education During and Post Covid-19 Pandemic at Colleges" was conducted as an effort to enrich additional knowledge about learning during and after the pandemic. This article aims to: first, describe the construction of daring lecture culture based on information technology and communication at every stage of Islamic education

\footnotetext{
${ }^{4}$ S.P. Robbins dan T.A. Judge, Perilaku Organisasi (Jakarta: Salemba Empat, 2007), 76

${ }^{5}$ Charles M. Regeluth, Instructional Design Theories and Models, An Overview of Their Current Status (New York: Routledge, 1999), 18 - 20.
} 
Nuraliah Ali \& Adilham: Daring Lecture Culture: Preference of Islamic Education Learning at College during and post Covid-19 Outbreak

learning. Second, describe the challenges of the construction of daring lecture culture on Islamic education at college.

\section{B. Method}

This type of research is qualitative descriptive research with an educational approach and information technology approach. This research aims to describe or display systematically, scientifically, and factual in the optimization of Information and technology products in each stage as the construction efforts of daring lectures. The method of collecting data to be used in this study is a content document. The content document is used to examine various scientific literature, both in the form of books, magazines, newsletters, newspapers, slide presentations, and so on related issues in this study. Review of literature or content document aims to thoroughly examine the contents of daring lecture culture information as well as strategies, challenges, and opportunities through existing literature or documents such as scientific journals, books, presiding articles, online articles, visual impressions, and videos. Data analysis techniques. The data obtained will be analyzed through the analysis of content or content analysis. Documents related to the research content are gathered and subsequently studied through the categorization phase. The process of data analysis on qualitative research is using latent content analysis. According to Julien that a deductive latent content analysis that starts from meticulously and in-depth text readings and attempts to discover text content that is still vague/hidden. ${ }^{6}$

\section{Construction of Daring Lecture Culture on Islamic Education Courses}

The discussion of the lecture is closely related to the discussion on learning. To build a lecture culture involves every component of the learning system. According to Djihad Hisyam, components of learning include: a) objectives, b) materials or materials, c) strategies and methods, d) media, e) educators, f) students, g) assessment, and evaluation. Lecturers should be able to synergize the learning components well to become a quality learning system. ${ }^{7}$ The integration of components in learning is one of

\footnotetext{
${ }^{6}$ H. Julien, Content Analysis, the Sage Encyclopedia of Qualitative Research Methods (Los Angeles, London, New Delhi, Singapore: SAGE, 2008), 86

${ }^{7}$ Suyanto \& Asep Jihad, Menjadi Guru Profesional: Strategi Meningkatkan Kualifikasi dan Kualitas Guru di Era Global (Jakarta: Esensi Erlangga Group, 2014), 98
} 
the determinants of success in learning. The overview of learning system components in each stage can be seen in the following figure 1:

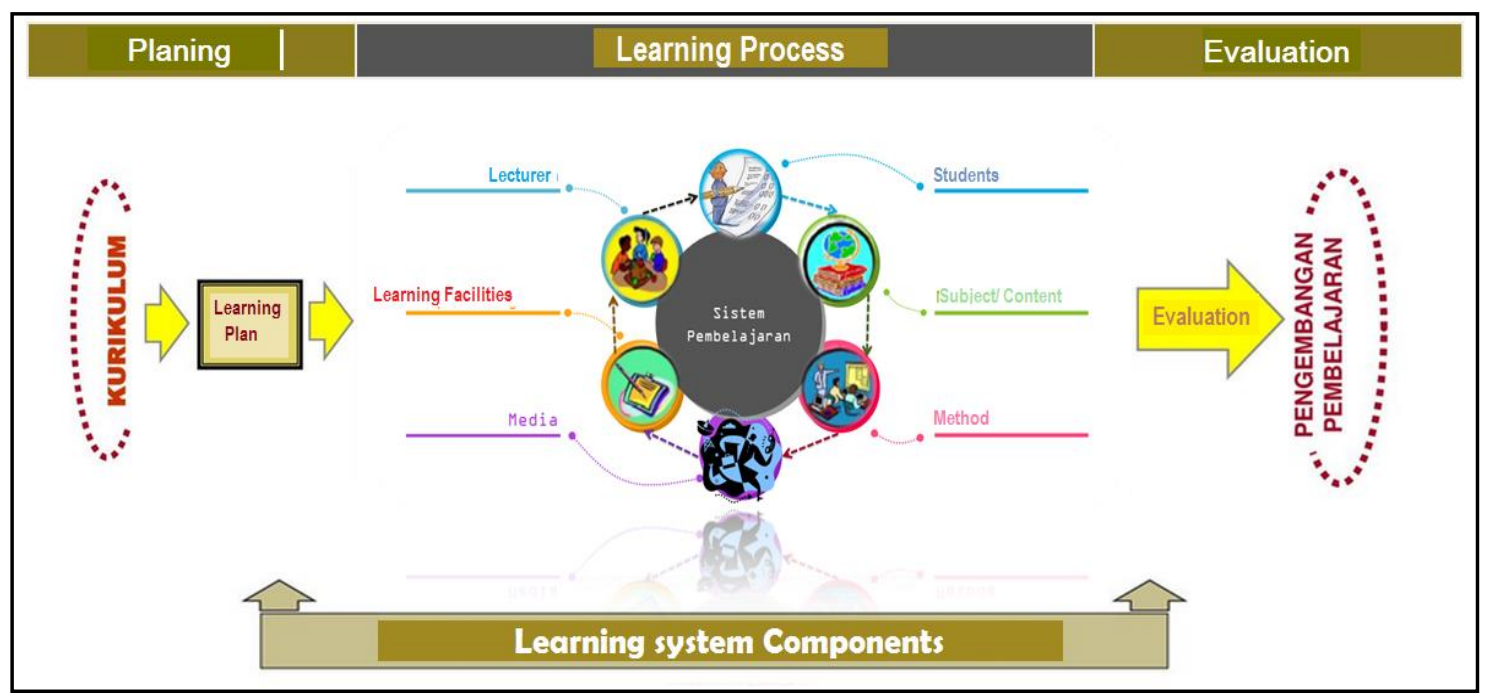

Figure 1. Components of Learning as a System

The daring lecture system on Islamic education learning can be done by adopting and integrating the device or technology products both in the form of software and hardware in every component/aspect of learning components. In this case, ICT has multi-role as a tool (supporting), supplementary, complement, enrichment, and substitute the traditional learning system. ${ }^{8}$

\section{Construction a Curriculum Based on ICT}

The curriculum is a component that must always be developed following the development of needs, science, technology, and able to answer the challenges of the Times. $^{9}$ The government through Presidential Instruction No. 6 of 2001 took steps on the implementation of ICT and its development plan in Indonesian education. The instruction was followed up in collaboration between ICT and ICT industry in education. ${ }^{10}$ Implementation of ICT development in education is conducted with the use of ICT as an essential part of learning the device curriculum in the education unit; Schools, colleges, and training centers. ${ }^{11}$ Sri Giarti in his journal states that ICT-based 79

${ }^{8}$ Munir, Dampak Teknologi Informasi dan Komunikasi dalam Pendidikan (Bandung: UPI 2008),

${ }^{9}$ Rusman, Deni Kurniawan, Cepi Riyana, Pembelajaran Berbasis Teknologi Informasi dan Komunikasi: Mengembangkan Profesionalitas Guru (Jakarta: PT. Rajagrafindo Persada, 2013), 112

${ }^{10}$ Riandi, "Aplikasi Teknologi Informasi dan Komunikasi (ICT) dalam Kurikulum Pendidikan Tinggi,” $\quad$ http://file.upi.edu/Direktori/FPMIPA/JUR._PEND._BIOLOGI/196305011988031-RIANDI/ Makalah-Artikel/Artikel_-Makalah-ICT_di_PT.pdf

${ }^{11}$ Tian Belawati, Pengembangan Bahan Ajar (Jakarta: Pusat Penerbitan UT, 2003), 134 
Nuraliah Ali \& Adilham: Daring Lecture Culture: Preference of Islamic Education Learning at College during and post Covid-19 Outbreak

curriculum management is a curriculum management system designed to facilitate teachers in the utilization of existing resources, through the activities of creating and developing cooperation, so that the learning form effectively and efficiently using multimedia learning media or ICT ${ }^{12}$. The scope of discussion on ICT-based curriculum in college can be seen in the following image 2 :

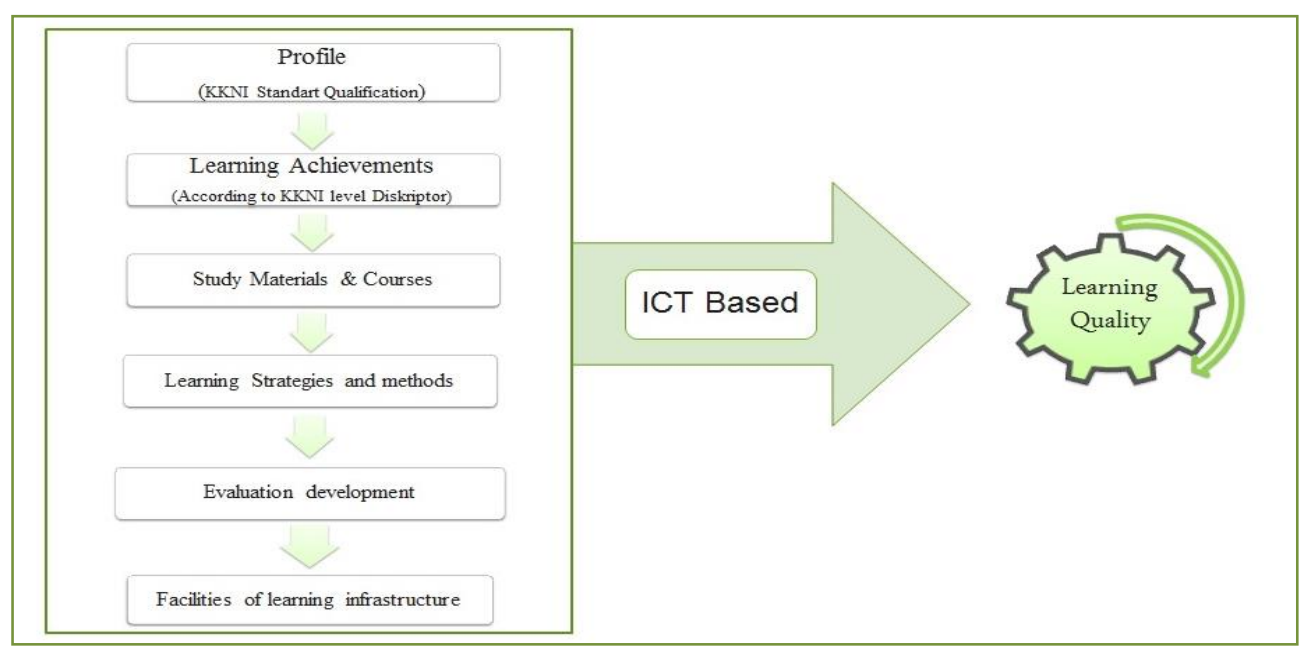

Figure 2. Designing ICT-based Curriculum Components in Colleges

The ICT-based curriculum still requires a more in-depth study of its implementation in learning. The application of ICT-based curriculum can be realized by optimizing the device/product information technology and communication at each stage of learning activities. The implementation of the ICT curriculum is a curriculum innovation that can meet the needs of the students in the present and future, especially post-pandemic Covid-19.

Integrating ICT into Islamic religious learning components needs to pay attention to several aspects such as expected outcomes, financing needed, responsible, resource requirements, and evaluation. ${ }^{13}$ Good planning will determine the implementation and execution of the results. In the planning phase of ICT integration in education components needed at least three stages namely ICT Strategic Planning, ICT management planning, ICT project Planning. ${ }^{14}$ The overview of the ICT integration process in learning components according to Munir ${ }^{15}$ can be seen in Figure 2 below:

\footnotetext{
${ }^{12}$ Sri Giarti, "Manajemen Kurikulum dan Pembelajaran Berbasis ICT," Satya Widya, Vol. 32, No. 2 (2016): 117-126.

${ }^{13}$ D. K. Rusman, \& C. Riyana, Pembelajaran Berbasis Teknologi Informasi dan Komunikasi (Bandung: Rajawali Pers, 2011), 68

${ }^{14}$ J. Ward, P. M. Griffiths, \& P. Whitmore, Strategic Planning for Information Systems 3rd Ed., XXVIII (UK: John Wiley \& Sons, Ltd, 2002)). See too, A. A. Setiyanti, D. T. Palekahelu \& E. Sediyono,
} 


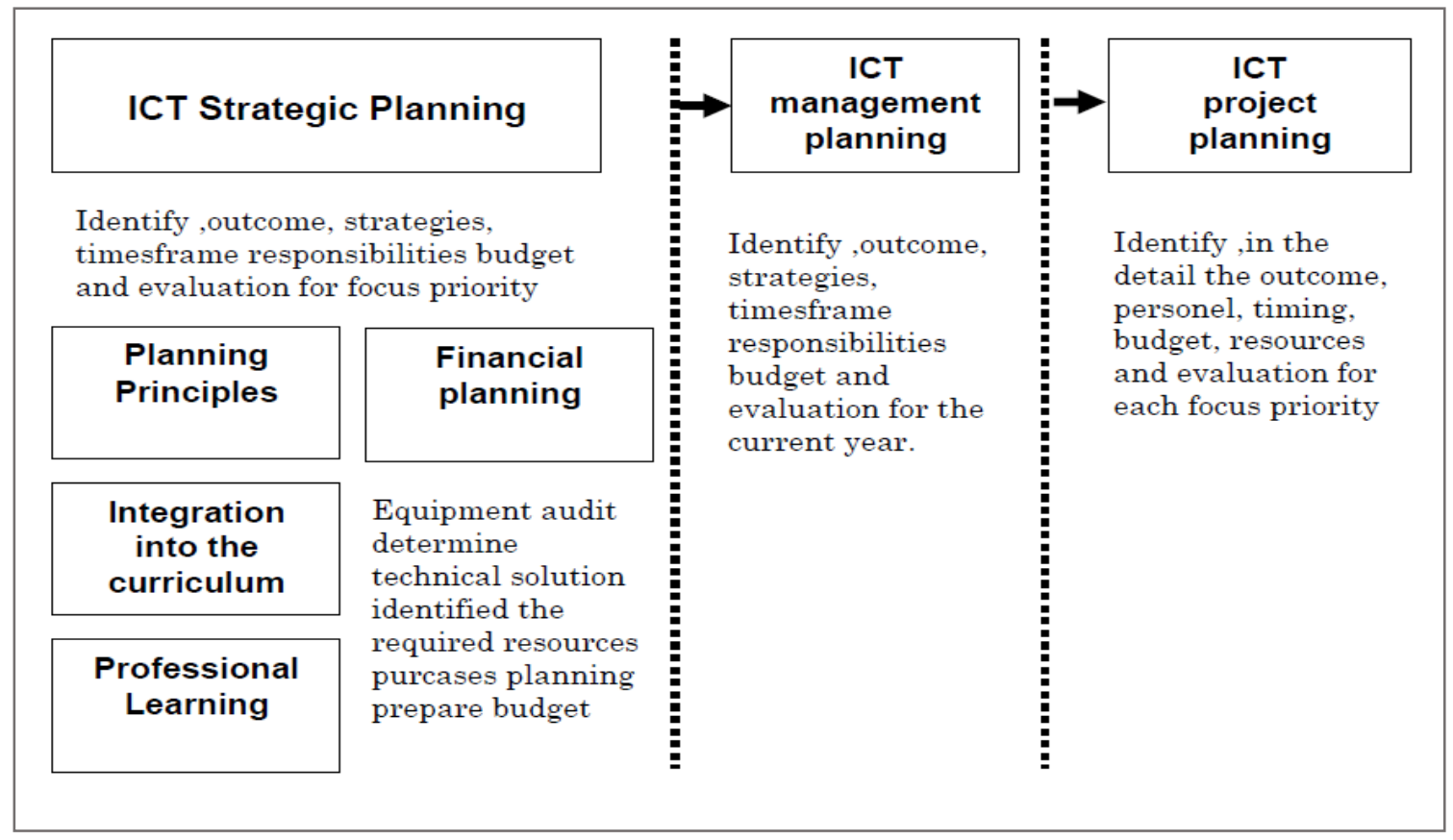

Figure 2. The Stages of ICT Planning

In the process of ICT strategic planning need to pay attention to the principles of planning as a basis to formulate ideal planning and per the planning study. Integration into the curriculum, ICT is used as a supporting, supplement, complement, enrichment, and substitution in fulfilling and achieving the target curriculum. The financial planning aspect is focused on obtaining the source of funding, accountability, accountability, and sustainability of ICT management. The stages of management planning and ICT project according to Bracewell, needs to identify the outcome or output to be achieved and the availability of resources capable of operating ICT devices. ${ }^{16}$

\section{Learning Resource}

Learning resources are references, objects, and materials used in learning activities ${ }^{17}$. In the context of learning resources, daring learning based on ICT serves as one of the effective learning resources, cheap, complete, and practical. ICT is defined as a set of technology tools used to access, create, urinate, store, and manage

\footnotetext{
"Perencanaan Pengembangan Sumber Daya Teknologi Informasi dan Komunikasi dalam Mendukung Rencana Strategis di Sekolah Menengah," Jurnal Buana Informatika, Vol. 7, No. 2 (2016): 96-97.

${ }^{15}$ Munir, Dampak Teknologi Informasi..., 82

${ }^{16} \mathrm{R}$. Bracewell, The Impulse Symbol: The Fourier Transform and its Applications (New York: McGrow-Hill,1999), 69-97.

${ }^{17}$ E. Mulysa, Kurikulum Tingkat Satuan Pendidikan (Bandung: PT Remaja Rosdakarya, 2010), 143
} 
Nuraliah Ali \& Adilham: Daring Lecture Culture: Preference of Islamic Education Learning at College during and post Covid-19 Outbreak

information. $^{18}$ The technology tools include a computer, internet, TV/radio broadcasting, and telephone. One of ICT's internet products is an amazingly great source of information called big data. Lecturers and students can utilize the internet as a learning resource. Some examples of internet implementation as learning resources can be seen in the following table:

\section{Tabel 1. Utilization of ICT as a Learning Resource}

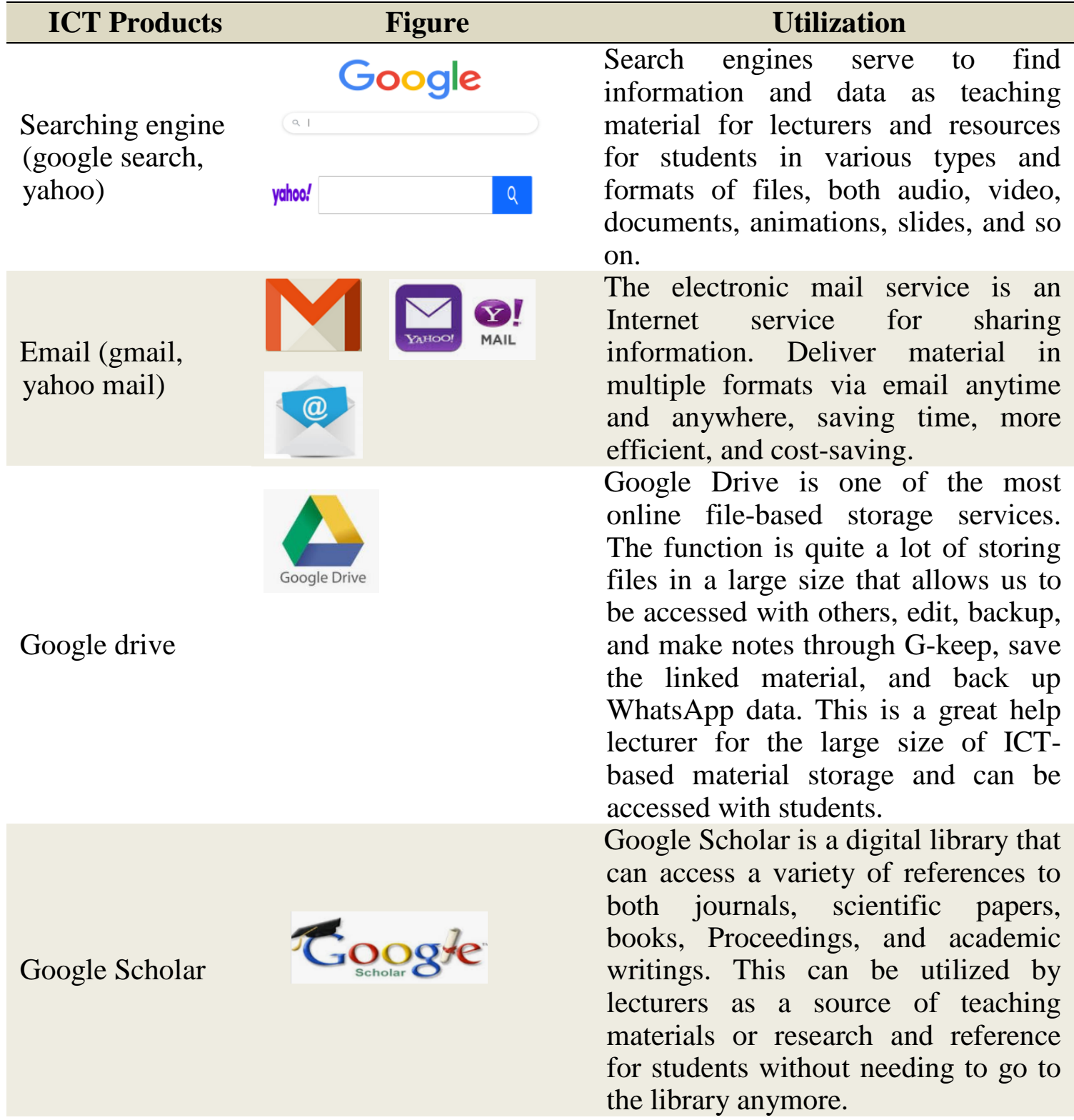

${ }^{18}$ M. Y. Rahim, "Pemanfaatan ICT sebagai Media Pembelajaran dan Informasi pada UIN Alauddin Makassar," Sulesana: Jurnal Wawasan Keislaman, Vol. 6, No. 2 (2016): 127-135. 


\begin{tabular}{lll}
\hline ICT Products & \multicolumn{1}{c}{ Figure } & \multicolumn{1}{c}{ Utilization } \\
\hline Social media & $\begin{array}{l}\text { Social Media can be used as a } \\
\text { common means of spreading and } \\
\text { sharing information between lecturers } \\
\text { and students. Lecturers can also } \\
\text { create student groups for information } \\
\text { sharing containers or discussions } \\
\text { through online forums. }\end{array}$ \\
\hline
\end{tabular}

Source: Processed from various sources

The training of daring learning based on ICT as a learning resource aims to stimulate the interests, thoughts, feelings, and attention of students so that learning and the atmosphere of the lecture can be more interactive, effective, and efficient. According to Zakiah and Irfan in his journal "The use of ICT as a source and medium of innovative learning in elementary school" explains that barriers to communication and interaction between educators and students can be addressed with the use of ICT as a source and learning medium to make learning more effective and interesting. ${ }^{19}$

\section{Learning Method}

Methods are a way of conveying specific materials, sciences, knowledge, skills, or attitudes, so learning can effectively, and the learning objectives can be accomplished well. $^{20}$ The utilization of daring learning can help students have an exhaustive understanding of the material, and students can improve their performance in the course with distance learning. Initially, daring/online learning was used to describe a learning system that utilizes Internet-based technology (computer-based learning/CBL). ${ }^{21}$ The ICT utilization strategy in the lecture consists of four things, namely ICT as learning aids or media, ICT as a learning tool, ICT as a learning resource, and ICT as professional enhancement. $^{22}$

Daring/online learning methods are essentially a way used by lecturers to transfer the learning material to students using the help of ICT devices such as

\footnotetext{
${ }^{19}$ S. Zakiah Dewi \& Irfan Hilman, "Penggunaan TIK sebagai Sumber dan Media Pembelajaran Inovatif di Sekolah Dasar," Indonesian Journal of Primary Education, Vol. 2, No. 2 (2018): 48-53.

${ }^{20}$ Ramayulis, Ilmu Pendidikan Islam, (Jakarta: Kalam Mulia, t.th.), 49. See too, Wina Sanjaya, Perencanaan dan Desain Sistem Pembelajaran (Jakarta: Kencana, 2002), 132, see too Ahmad Sabri, Strategi Belajar Mengajar dan Micro Teaching, Quantum Teaching (Ciputat: t.p., 2005), 21

${ }^{21}$ E. Kuntarto, "Keefektifan Model Pembelajaran Daring dalam Perkuliahan Bahasa Indonesia di Perguruan Tinggi," Indonesian Language Education and Literature, Vol. 3, No. 1 (2017): 101.

${ }^{22}$ Sahid, "Pengembangan Media Pembelajaran Berbasis ICT (Information communication and Technology), Bahan Ajar (Yogyakarta Universitas Negeri Yogyakarta, 2010), 34
} 
computers, LCD, and digital content. According to Rasim in his journal that computerbased learning methods can provide visualization of abstract material, which can help students learn without being limited to space and time. Computer-based learning methods can use a variety of learning media so that the science transfer presentation is more interactive. ${ }^{23}$ In subsequent developments, the function computer has been replaced by a mobile phone or a gadget device. Learning can more flexible than using a computer. Students can learn anywhere, anytime, and in any situation. The lecture is not only can be done through a face-to-face process between lecturers and students due to the ongoing pandemic situation. Now students can learn despite the distance with the lecturers far apart.

Several daring implementations in the development of learning models can be done, with a computer-based learning model, drills, tutorial, simulation, instructional games, web-based learning, and e-learning. In Indonesia, e-learning is an alternative learning method during and post-the Covid-19 pandemic. Lecturers on Islamic religious education courses can utilize the e-learning model as a revolution in the learning system of Islamic religious education in the college post-pandemic Covid-19. E-learning is a learning method that in the implementation using the help of information and computer technology products such as the Internet, computer, mobile phone, etc. ${ }^{24}$ E-learning has been considered the best possible approach to continue the teaching and learning process during the pandemic. ${ }^{25}$ Implementation e-learning in class must contain the elearning components as illustrated in the following image 4:

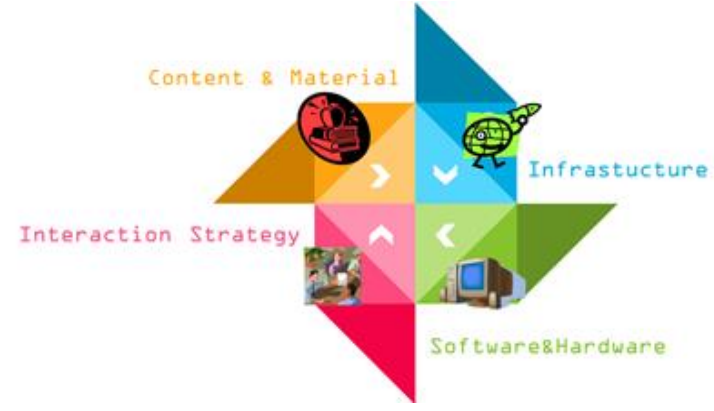

Figure 3. E-Learning Components

\footnotetext{
${ }^{23}$ Rasim, Wawan Setiawan, Eko Fitrijaya Rahman, "Metodologi Pembelajaran Berbasis Komputer dalam Upaya Menciptakan kultur Pembelajaran Berbasis Teknologi Informasi dan Komunikasi," https://adoc.pub/metodologi-pembelajaran-berbasis-komputer-dalam-upaya-mencip.html

${ }^{24}$ A. Kusmana, "E-learning dalam Pembelajaran," Lentera Pendidikan: Jurnal Ilmu Tarbiyah dan Keguruan, Vol. 14, No. 1 (2017): 35-51.

${ }^{25}$ A. Almanthari, S. Maulina \& S. Bruce, “Secondary School Mathematics Teachers' Views on Elearning Implementation Barriers during the COVID-19 Pandemic: The Case of Indonesia," Eurasia Journal of Mathematics, Science and Technology Education, Vol. 16, No. 7 (2020): 1
} 
E-learning as a system can not stand alone because every component has a strategic role. In e-learning, the first thing to note is the availability of the infrastructure components are capable. The e-learning infrastructure includes computer networks, Internet networks, multimedia equipment, teleconference equipment on synchronous learning services through teleconference. The next component is the system e-learning is application software. A software system that virtualized the conventional teaching and learning process. How to class management, material or content creation, discussion forum, assessment system, online exam system, and all features related to the management of teaching and learning process. The software is known as a Learning Management System (LMS). The last component of e-learning is the content of elearning. The content or materials that exist on the LMS e-learning can be in the form of multimedia-based content or text-based content such as text in ordinary textbooks. Commonly stored in the Learning Management System (LMS) so that students can access the learning material anytime and anywhere.

4. Learning Media

Media has a strategic role in the learning process. Learning media is a tool/means that help in the process of transferring knowledge, know-how, messages, information from lecturers to students. Learning media aims to stimulate the mind, feelings, attention, interests, and attention of students in learning to be called with. In the course of ICT-based lecturers can integrate the devices or products ICT results as a means of transferring information in the course of the lecture. The use of ICT as a media can be done in the form of CAI program software, slide power points containing animated images, video, audio, simulation programs, and more. The use of ICT-based learning media has been used in the learning process in almost all fields of science and also on Islamic education courses. Lecturers who teach Islamic education courses must have competence, in the development of learning, lecturers also are required to compete and develop their skills with the use of ICT products, especially computers. ${ }^{26}$

ICT-based lecturing requires media or assistive devices for both hardware and software in its development. For hardware or hardware can be a computer, notebook, LCD, television, projector, camera, printer, scanner, speaker, microphone, storage media (flash, CD/DVD room, external HD), etc. The use of software in e-learning can

\footnotetext{
${ }^{26}$ S. Pulungan, "Pemanfaatan ICT dalam Pembelajaran PAI," Query: Journal of Information Systems, Vol. 1, No. 01 (2017), 20
} 
use the software that has been widely available, both free and commercial software.

The details on the utilization of ICT-based media can be relieved in the following table:

Table 2. Utilization of ICT as a Learning Media

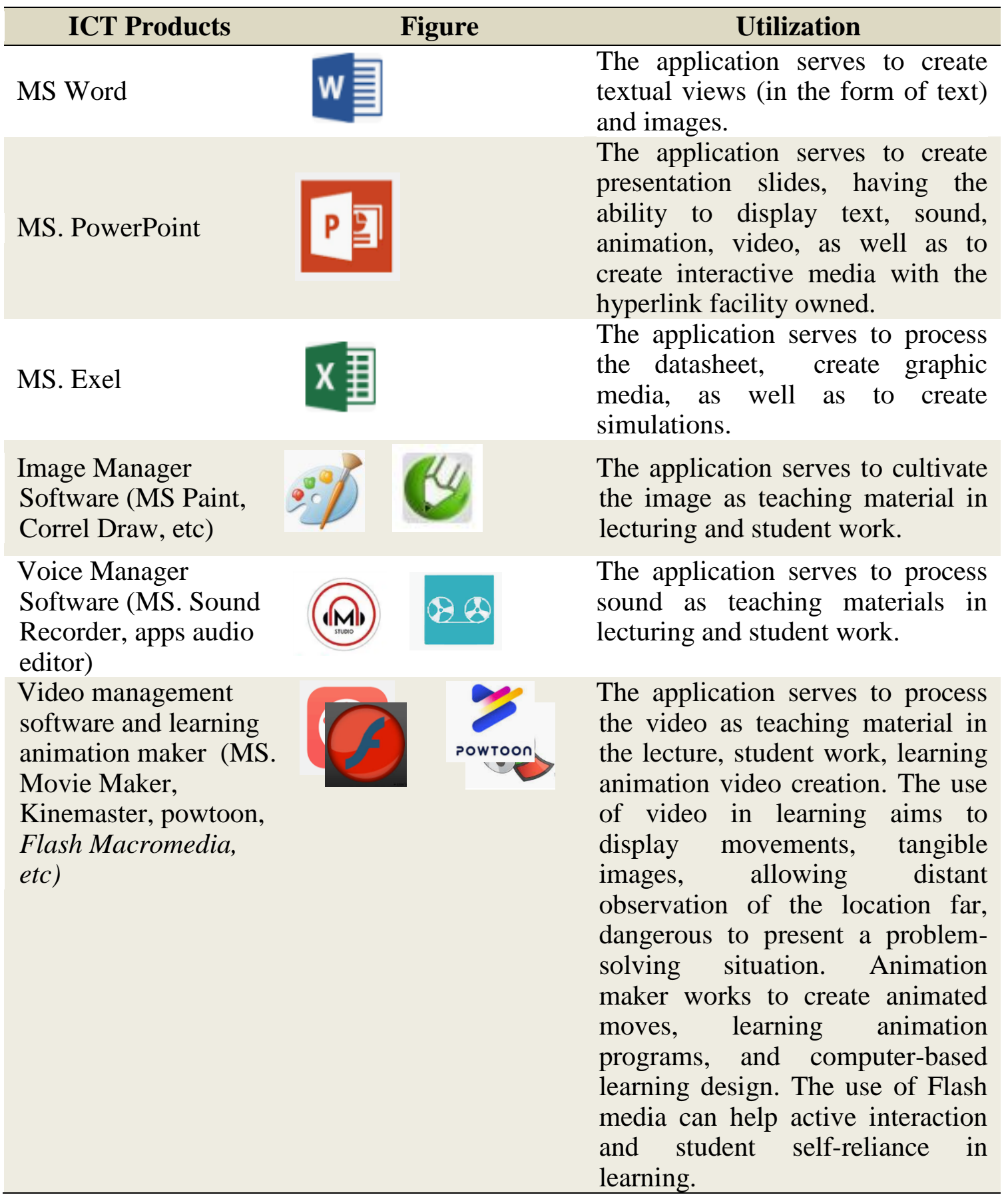

Source: Processed from various sources

Software development media-based learning information and communication technology including, commercial software (sold publicly), WebCT, Macromedia Authorware, Macromedia Flash, Knowledge Presenter, Free Software (free), etc. 


\section{Assessment and Evaluation}

Evaluation is a teacher's activity to assess and determine the level of student success in a planned, systematic, and directional manner based on learning objectives. According to Gronlund and Linn's opinion that the evaluation of learning is a process of collecting, analyzing, and interpreting the information system to determine the extent of the learning objectives. ${ }^{27}$ Development of assessment test by using information and communication technology facility based on the type of objective test and non-objective test. Objective tests include true-false, multiple-choice, multi-select, please (to reconclish). Non objective tests include jumble exercise (composing letters/words), fill in the blank (close activity), and crossword. Besides, learning assessments can utilize the software. The software to create the interactive test is Hot Potatoes, Quiz Maker (Desktop and Web basic application), ${ }^{28}$ can be relieved in the following table 3:

\section{Table 3. Utilization ICT for the Interactive Test}

\begin{tabular}{|c|c|c|}
\hline ICT Products & Figure & Utilization \\
\hline Hot Potatoes software & & $\begin{array}{l}\text { Hot Potatoes is an application } \\
\text { that functions to create } \\
\text { interactive quizzes in HTML } \\
\text { (Hypertext Markup Language) } \\
\text { format. This Hot Potatoes } \\
\text { application can create several } \\
\text { quiz formats. For versions } 6.0 \\
\text { and up there are five main } \\
\text { menus, namely JQuiz, JMix, } \\
\text { JCross, JMatch, and JCloze. }\end{array}$ \\
\hline \multirow{3}{*}{$\begin{array}{l}\text { Quiz Maker software } \\
\text { (Desktop and Web basic } \\
\text { application) }\end{array}$} & Q. Wondershare QuizCreator & $\begin{array}{l}\text { Quiz Maker is a desktop-based } \\
\text { or web-based application that } \\
\text { provides easy quiz creation } \\
\text { features. WondershareApp and } \\
\text { iSpiring quiz App are desktop- }\end{array}$ \\
\hline & $\nabla_{\text {i iSpring QuizMaker }}$ & $\begin{array}{l}\text { based applications that can be } \\
\text { used to create interactive flash- } \\
\text { based quizzes and Proprofs is a }\end{array}$ \\
\hline & Pro Profis & $\begin{array}{l}\text { web-based application quiz } \\
\text { maker. }\end{array}$ \\
\hline
\end{tabular}

${ }^{27}$ N. E. Gronlund \& R. L. Linn, Measurement and Evaluation in Teaching (New York: MacMillan Publishing Company, 1990), 98

${ }^{28}$ A. Asrul, R. Ananda \& R. Rosnita, Evaluasi Pembelajaran (Bandung: Citapustaka Media, 2015), 45-54 


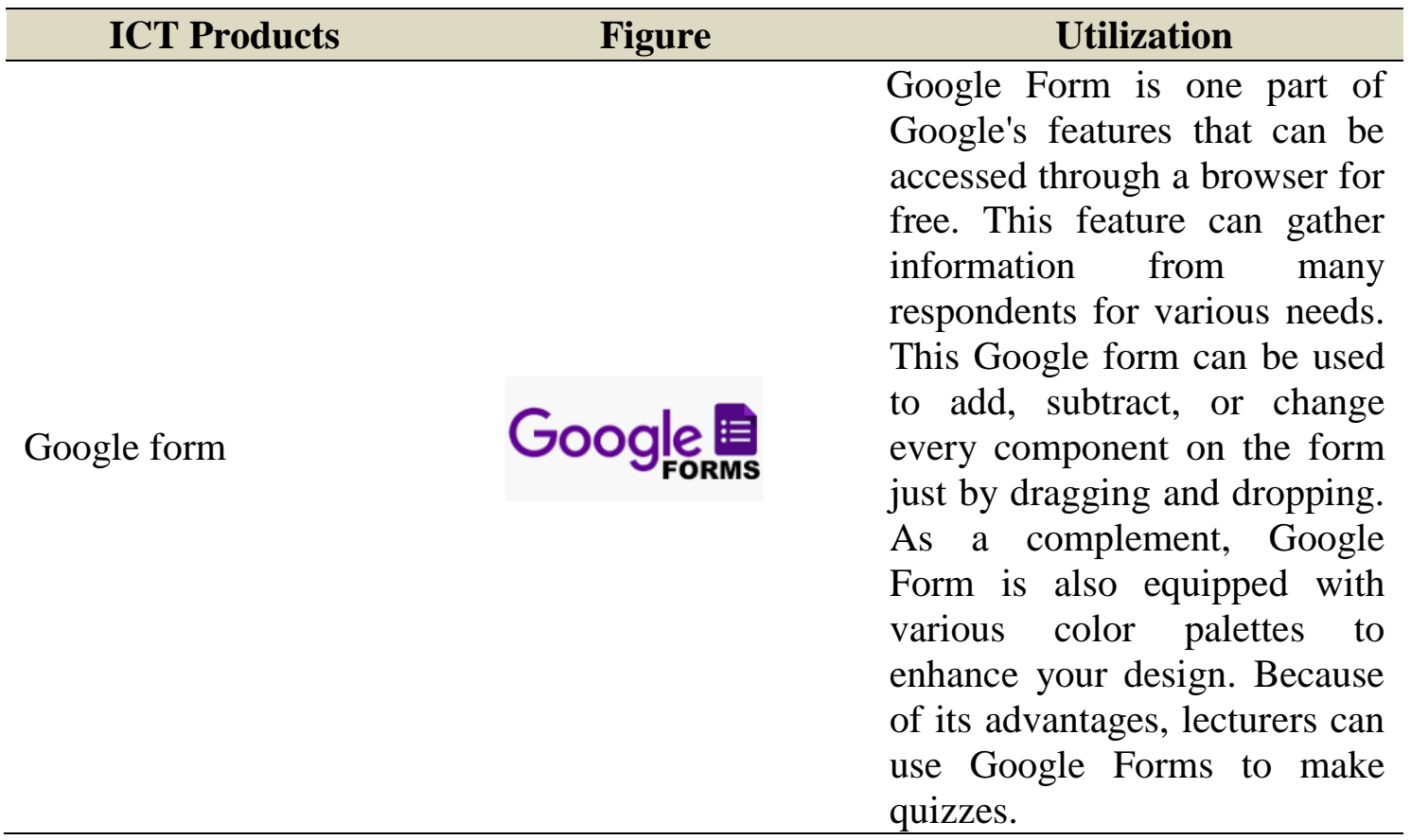

Source: Processed from various sources

\section{The Challenges of the Daring Lecture Culture Construction on Islamic Education Lecture}

At the beginning of March 2020, the Indonesian government announced the COVID-19 as a national disaster. The Ministry of Education and Culture issued a policy for every unit of education ranging from basic education (elementary schools) to higher education to transform a face to face learning into distance-learning or online lectures. The decision adopted by the Government as an attempt to break the COVID-19 spread chain, forcing each college to adapt instantly. But the sudden change, making a surprise for everyone because of the gaps and problems of sharing aspects that cause not all students can get good quality learning through online courses.

In the context of Islamic religious education, distance education or online lectures have a considerable impact on the need for attention because Islamic education is not only responsible for cognitive aspect or brain consumption but also responsible for students' attitudes, akhlak, and morality. ${ }^{29}$

Therefore, lecturers need to create a culture of daring/online lecturing as a revolution in learning during and post the COVID-19 pandemic. Constructing a

\footnotetext{
${ }^{29}$ N. Ali, "Measuring Religious Moderation Among Muslim Students at Public Colleges in Kalimantan Facing Disruption Era," INFERENSI: Jurnal Penelitian Sosial Keagamaan, Vol. 14, No. 1 (2020): 1-24. See too, N. Ali \& S. Noor, "Pendidikan Islam Multikultur: Relevansi, Tantangan, dan Peluang," Jurnal Hadratul Madaniyah, Vol. 6, No. 1, (2019): 24-42.
} 
daring/online lecture is not an easy thing. Some many weaknesses and shortcomings need to be addressed to apply learning that uses technology in colleges. The challenges of the cultural construction of daring learning on Islamic education lecture, including:

\section{Capable Infrastructure}

The first thing to note in daring learning based on ICT, especially on distance learning, is the availability of capable infrastructure. Infrastructure in question is the availability of internet networks with wide bandwidth. Broadband internet access is an important element in daring learning because the learning method uses an audio-visual method that requires a large connection capacity. Indonesia does not currently provide information and communication technology (ICT) infrastructure, a major prerequisite for distance learning, which is adequate and widespread for all its citizens.

Quoted from the latest International Telecommunication Union (ITU) and the Central Statistic Agency (in Indonesia, Badan Pusat Statistik) shows that data on ownership and use of information and communication technology from Indonesia is still in low. It can be seen on the proprietary data and the use of information technology and communications from Indonesia residents from 2009-2018 released by the International Telecommunication Union (ITU) ${ }^{30}$ at 2019 as shown in the following chart:

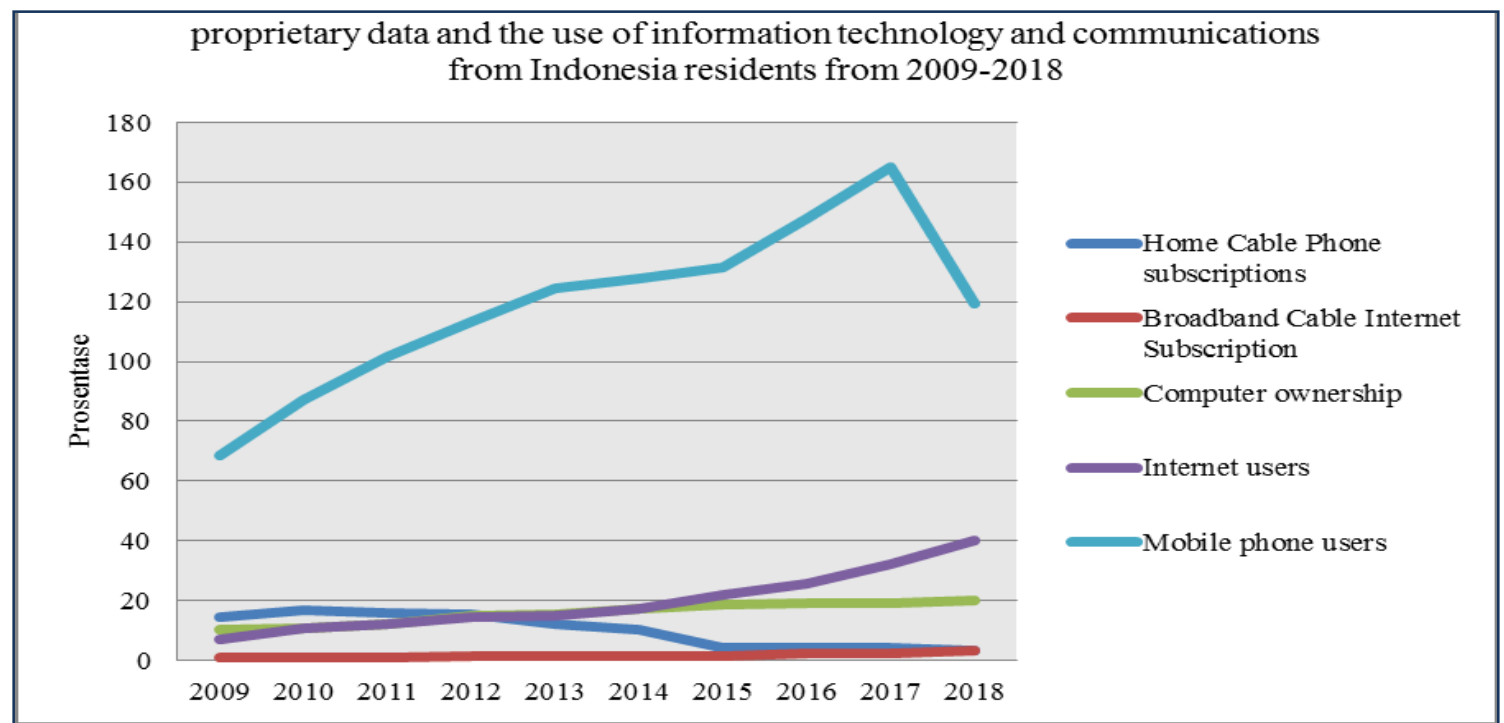

Source: International Telecommunication Union (ITU), BPS Indonesia, Whisnu Triwibowo

\footnotetext{
${ }^{30}$ International Telecommunication Union (ITU), "Yearbook of Statistics Telecommunication/ICT Indicators - 2009-2018," avaliable on https://www.itu.int/pub/D-IND-YB-2019. See also on Whisnu Triwibowo, "Gagap 3 Aspek Vital: Kuliah Online di Tengah COVID-19 Bisa Perparah Gap Akses Pembelajaran Bermutu bagi Mahasiswa Miskin," avaliable on https://theconversation.com/gagap-3-aspek-vital-kuliah-online-di-tengah-covid-19-bisa-perparah-gapakses-pembelajaran-bermutu-bagi-mahasiswa-miskin-134933.
} 
Although almost all mobile phone operators in Indonesia already offer a 4G LTE connection, the quality of the connection is not always stable is still a big constraint. Although there is fast internet access, not all residents can purchase access. The inequitable infrastructure that supports the application of ICT in education is an initial problem that must be resolved by the authorities because, without the support of infrastructure, the application of ICT in the field of education will only be a mere dream. Infrastructure is a very important component that serves as the initial and major capital in the application of ICT in education. At this time, there is a tendency that only certain areas get ICT access. This is because there are still many areas that even have access to the telephone and networking does not exist, especially for access to the internet.

\section{Socio-economic Factors}

The socio-economic status of the user affects the level of competency and literacy. Learners who come from less capable people may not have a computer and can not access an Internet connection, thus experiencing limited physical access and digital technology material. Even though they are from native digital generation, their digital skills will be lower than the students of the family who are more residing. The limitation of economic resources creates a digital divide among millennials, especially regarding the use of various applications and internet quota access. Students who have the financial ability more able to explore the internet and its applications so that they are familiar and can adapt quickly. While the students who have economic limitations will be missed because it is not able to buy Internet data quota. So there is a close connection between social gaps, access availability, and digital skills.

3. The unpreparedness of human resources

Another obstacle in the application of daring learning based on ICT is the human resource unpreparedness to utilize technological products in the learning process. This unpreparedness is due to the classical pattern of learning habits and does not want to go out of comfort zones. Sometimes this obstacle is much harder to solve than the absence of infrastructure that supports daring/ online. It is usually more difficult to change the pattern of behavior/habit of a person. Therefore, there needs to be aware of each learner to utilize and apply ICT in its method of learning. According to Mahmudin his book titled ICT for High School, there are several requirements to apply to learn technology- 
based information and communication ${ }^{31}$, namely 1) the availability of infrastructure that supports ICT-based learning; 2) Available material of quality, meaningful, and cultural support for learners and teachers, there is sufficient budget or funds to hold, develop and maintain such information technology and communication infrastructure, and 3) human resource support ready for ICT use in learning.

In addition to the several conditions that have been submitted, there is an important aspect in the implementation of daring/online learning based on ICT that is the willingness of all parties, in this case, lecturers and students to implement learning with the support of such communications and information technology. However, some research results suggest that the unpreparedness of educators and students to utilize technological products in the learning process becomes a constraint in the application of online learning. This unpreparedness is due to several factors, both internal and external factors. Some factors that influence the readiness of human resources facing daring learning are:

\section{a. Inherent resistance to change}

The habit of teachers and students who prefer classical learning and do not want to leave the comfort zone is a major obstacle in ICT-based learning. This obstacle is much harder to solve than the absence of infrastructure that supports ICT. It is usually more difficult to change the pattern of behavior or habit of a person. Changes to face-toface methods in the class become mediated via a laptop screen requiring adaptation and change, especially from the material setup and interaction side of the virtual space. Teachers who do not have the digital skills and knowledge of adequate technological characteristics will be hampered so as not to achieve the prescribed learning objectives. Therefore, there needs to be aware of each learner to utilize and apply ICT in its method of learning.

\section{b. Attitude and personality}

The confidence of lecturers who lack deep in terms of utilizing ICT products in the teaching and learning process can be an obstacle in daring/online learning. According to Papanastasiou and Angeli ${ }^{32}$, beliefs and attitudes are important factors for

${ }^{31}$ Ismail Isjoni \& R. Mahmud, ICT untuk Sekolah Unggul (Yogyakarta: Pustaka Pelajar, 2008),

${ }^{32}$ E. C. Papanastasiou \& C. Angeli, "Evaluating the Use of ICT in Education: Psychometric Properties of the Survey of Factors Affecting Teachers Teaching with Technology SFA-T3," Educational Technology \& Society, Vol. 11, No. 1 (2008): 69-86. 
how teachers use ICT in teaching activities. As such, the teacher's attitude towards ICT is an important factor when applying ICT in daring teaching. Lecturers are afraid of failing to teach through the use of ICT which is currently very important. According to Basak and Govender, one attitude teachers have, at all levels, is the lack of trust to use ICT in their teaching. ${ }^{33}$ Many teachers fear using ICT in their teaching and become anxious when having to use their ICT knowledge. Besides, many teachers also lack knowledge of the benefits of ICT in education. ${ }^{34}$ If they do not have a good grasp of the potential benefits of using ICT in teaching, they may not have the motivation to integrate ICT with teaching activities.

The fear can be a plainness in the adoption of technology. Empirical evidence to claim that teacher confidence about teaching practice is important in explaining why teachers adopt digital technology for teaching. The availability of various applications that can be used in distance learning, such as WhatsApp, Google Meet, Zoom, and Line has led to new challenges. Each application has special characteristics that will affect the interaction between students and lecturers. The main concern is the impact of the application on the quality of learning outcomes. Teachers must understand the technological characteristics used in distance learning, especially concerning knowledge of the advantages and disadvantages of applications used. Ward and Parr ${ }^{35}$ show that teachers who understand the benefits of using digital technology to teach and learn are more likely to use digital technology at school. The challenge gives the teacher pressure on the choice of whether to choose to implement the use of ICT products in daring learning or return to the comfort zone using classical learning.

\section{c. Lack of digital competency of teachers}

Constraint referred here is a lack of competency of teachers in integrating ICT into the pedagogical practice, i.e., not having knowledge and skills in using the computer and not enthusiastic about the change and integration with learning using technology in their classrooms. Although ICT tools are increasingly popular, many

${ }^{33}$ S. K. Basak and D. W. Govender, "Development of a Conceptual Framework Regarding the Factors Inhibiting Teachers' Successful Adoption and Implementation of ICT in Teaching and Learning," The International Business \& Economics Research Journal Online, Vol. 14 No. 3 (2015): $431-438$

${ }^{34}$ H. Mirzajani, R. Mahmud, A. Fauzi Mohd. Ayub, and S. L.Wong, "Teachers' Acceptance of ICT and its Integration in the Classroom," Quality Assurance in Education, Vol. 24, No. 1 (2016): 26-40.

${ }^{35} \mathrm{~L}$. Ward and J. M. Parr, "Revisiting and Reframing Use: Implications for the Integration of ICT," Computers \& Education, Vol. 54, No. 1 (2010): 113-122 
teachers still have the challenge of integrating ICT tools into learning activities. ${ }^{36}$ The competence and literacy of computers and surfing in cyberspace are the basic skills required in ICT-based learning. Educators and learners are required to be able to have the ability to operate and access digital and Internet technologies in classrooms, schools, and educational institutions. Teachers must have the knowledge and skills to use tools and digital resources to help learners achieve academic standards. Teachers face many challenges when trying to integrate ICT in their teaching, and some of them are their knowledge, skills, and confidence.

\section{E. Conclusion}

One of COVID-19's during and post-pandemic learning preferences is daring learning or distance learning. The effort to build a culture of daring online lectures on Islamic religious Studies in college is not easy. The challenge faced in building a culture of online lectures is a capable infrastructure as a foundation of online learning, socio-economic factors, the unpreparedness of human resources in the form of resistance to change, attitude, and confidence of lecturers, lack of digital skills, and the accessibility of uneven resources. Constructing the culture of daring lectures on Islamic education needs to pay attention to several aspects namely expected outcomes, required financing, responsibilities, resource requirements, and evaluation. Governments should respond quickly and provide solutions to every challenge, as well as supervise the learning process during and post-pandemic, and when it comes to revising on various aspects to improve deficiencies, especially concerning availability resource access and improving digital skills. There must be a formative evaluation and strategic policy during the online/online learning process. Because we do not know when this Covid-19 pandemic will be over exactly.

\section{F. References}

Ali, N. "Measuring Religious Moderation Among Muslim Students at Public Colleges in Kalimantan Facing Disruption Era." INFERENSI: Jurnal Penelitian Sosial Keagamaan, Vol. 14, No. 1 (2020): 1-24.

\footnotetext{
${ }^{36}$ K. Nikolopoulou and V. Gialamas, "Barriers to ICT Use in High Schools: Greek Teachers' Perceptions," Journal of Computers in Education, Vol. 3, No. 1 (2016): 59-75.
} 
Nuraliah Ali \& Adilham: Daring Lecture Culture: Preference of Islamic Education Learning at College during and post Covid-19 Outbreak

Ali, N. \& S. Noor. "Pendidikan Islam Multikultur: Relevansi, Tantangan, dan Peluang." Jurnal Hadratul Madaniyah, Vol. 6, No. 1, (2019): 24-42.

Almanthari, A., S. Maulina \& S. Bruce. "Secondary School Mathematics Teachers' Views on E-learning Implementation Barriers during the COVID-19 Pandemic: The Case of Indonesia." Eurasia Journal of Mathematics, Science and Technology Education, Vol. 16, No. 7 (2020): 1

Asrul, A., R. Ananda \& R. Rosnita. Evaluasi Pembelajaran. Bandung: Citapustaka Media, 2015.

Bao, V., Y. Sun, S. Meng, J. Shi, L. Lu. "2019-nCoV Epidemic: Address Mental Health Care to Empower Society." Lancet 395 (10224), e37-e38. London: England, 2020.

Basak, S. K. and D. W. Govender. "Development of a Conceptual Framework Regarding the Factors Inhibiting Teachers' Successful Adoption and Implementation of ICT in Teaching and Learning." The International Business \& Economics Research Journal Online, Vol. 14 No. 3 (2015): 431-438

Belawati, Tian. Pengembangan Bahan Ajar. Jakarta: Pusat Penerbitan UT, 2003

Bracewell, R. The Impulse Symbol: The Fourier Transform and its Applications. New York: McGrow-Hill,1999.

Chen, Q., M. Liang, Y. Li, J. Guo, D. Fei, L. Wang, L. He, C. Sheng, Y. Cai, X. Li, J. Wang, Z. Zhang. "Mental Health Care for Medical Staff in China during the COVID-19 Outbreak." The Lancet Psychiatry, 2020a.

Dewi, S. Zakiah \& Irfan Hilman. "Penggunaan TIK sebagai Sumber dan Media Pembelajaran Inovatif di Sekolah Dasar." Indonesian Journal of Primary Education, Vol. 2, No. 2 (2018): 48-53.

Giarti, Sri. "Manajemen Kurikulum dan Pembelajaran Berbasis ICT." Satya Widya, Vol. 32, No. 2 (2016): 117-126.

Gronlund, N. E. \& R. L. Linn. Measurement and Evaluation in Teaching. New York: MacMillan Publishing Company, 1990

International Telecommunication Union (ITU). "Yearbook of Statistics Telecommunication/ICT Indicators - 2009-2018." Avaliable on https://www.itu.int/pub/D-IND-YB-2019.

Isjoni, Ismail \& R. Mahmud. ICT untuk Sekolah Unggul. Yogyakarta: Pustaka Pelajar, 2008

Julien, H. Content Analysis, the Sage Encyclopedia of Qualitative Research Methods. Los Angeles, London, New Delhi, Singapore: SAGE, 2008.

Kuntarto, E. "Keefektifan Model Pembelajaran Daring dalam Perkuliahan Bahasa Indonesia di Perguruan Tinggi." Indonesian Language Education and Literature, Vol. 3, No. 1 (2017): 101.

Kusmana, A. "E-learning dalam Pembelajaran." Lentera Pendidikan: Jurnal Ilmu Tarbiyah dan Keguruan, Vol. 14, No. 1 (2017): 35-51. 
Mirzajani,H., R. Mahmud, A. Fauzi Mohd. Ayub, and S. L. Wong. "Teachers' Acceptance of ICT and its Integration in the Classroom." Quality Assurance in Education, Vol. 24, No. 1 (2016): 26-40.

Mulyasa, E. Kurikulum Tingkat Satuan Pendidikan. Bandung: PT Remaja Rosdakarya, 2010

Munir. Dampak Teknologi Informasi dan Komunikasi dalam Pendidikan. Bandung: UPI 2008

Nikolopoulou, K. and V. Gialamas. "Barriers to ICT Use in High Schools: Greek Teachers' Perceptions." Journal of Computers in Education, Vol. 3, No. 1 (2016): 59-75.

Pan , X., D.M. Ojcius, T. Gao, Z. Li, C. Pan. "Lessons Learned from the 2019-nCoV Epidemic on Prevention of Future Infectious Diseases." Microbes and Infection/Institut Pasteur 22 (2) 2020: 86-91

Papanastasiou, E. C. \& C. Angeli. "Evaluating the Use of ICT in Education: Psychometric Properties of the Survey of Factors Affecting Teachers Teaching with Technology SFA-T3." Educational Technology \& Society, Vol. 11, No. 1 (2008): 69-86.

Pulungan, S. "Pemanfaatan ICT dalam Pembelajaran PAI." Query: Journal of Information Systems, Vol. 1, No. 01 (2017), 20.

Rahim, M. Y. "Pemanfaatan ICT sebagai Media Pembelajaran dan Informasi pada UIN Alauddin Makassar," Sulesana: Jurnal Wawasan Keislaman, Vol. 6, No. 2 (2016): 127-135.

Ramayulis. Ilmu Pendidikan Islam. Jakarta: Kalam Mulia, t.th.

Rasim, Wawan Setiawan, Eko Fitrijaya Rahman. "Metodologi Pembelajaran Berbasis Komputer dalam Upaya Menciptakan Kultur Pembelajaran Berbasis Teknologi Informasi dan Komunikasi." https://adoc.pub/metodologi-pembelajaranberbasis-komputer-dalam-upaya-mencip.html

Regeluth, Charles M. Instructional Design Theories and Models, An Overview of Their Current Status. New York: Routledge, 1999.

Riandi. "Aplikasi Teknologi Informasi dan Komunikasi (ICT) dalam Kurikulum Pendidikan http://file.upi.edu/Direktori/FPMIPA/JUR._PEND._BIOLOGI/

Tinggi." 196305011988031-RIANDI/Makalah-Artikel/Artikel_-Makalah-ICT_di_PT.pdf

Robbins, S.P. dan T.A. Judge. Perilaku Organisasi. Jakarta: Salemba Empat, 2007

Rusman, D. K. \& C. Riyana. Pembelajaran Berbasis Teknologi Informasi dan Komunikasi. Bandung: Rajawali Pers, 2011

Rusman, Deni Kurniawan, Cepi Riyana. Pembelajaran Berbasis Teknologi Informasi dan Komunikasi: Mengembangkan Profesionalitas Guru. Jakarta: PT. Rajagrafindo Persada, 2013.

Sabri, Ahmad. Strategi Belajar Mengajar dan Micro Teaching: Quantum Teaching Ciputat: t.p., 2005 
Nuraliah Ali \& Adilham: Daring Lecture Culture: Preference of Islamic Education Learning at College during and post Covid-19 Outbreak

Sahid. "Pengembangan Media Pembelajaran Berbasis ICT (Information communication and Technology). Bahan Ajar. Yogyakarta Universitas Negeri Yogyakarta, 2010

Sanjaya, Wina. Perencanaan dan Desain Sistem Pembelajaran. Jakarta: Kencana, 2002

Setiyanti, A. A., D. T. Palekahelu \& E. Sediyono. "Perencanaan Pengembangan Sumber Daya Teknologi Informasi dan Komunikasi dalam Mendukung Rencana Strategis di Sekolah Menengah." Jurnal Buana Informatika, Vol. 7, No. 2 (2016), 96-97.

Suyanto \& Asep Jihad. Menjadi Guru Profesional: Strategi Meningkatkan Kualifikasi dan Kualitas Guru di Era Global. Jakarta: Esensi Erlangga Group, 2014.

Triwibowo, Whisnu. "Gagap 3 Aspek Vital: Kuliah Online di Tengah COVID-19 Bisa Perparah Gap Akses Pembelajaran Bermutu bagi Mahasiswa Miskin.” Avaliable on https://theconversation.com/gagap-3-aspek-vital-kuliah-online-di-tengahcovid-19-bisa-perparah-gap-akses-pembelajaran-bermutu-bagi-mahasiswamiskin-134933.

Ward, J., P. M. Griffiths, \& P. Whitmore, Strategic Planning for Information Systems 3rd Ed. XXVIII. UK: John Wiley \& Sons, Ltd, 2002

Ward, L., and J. M. Parr. "Revisiting and Reframing Use: Implications for the Integration of ICT." Computers \& Education, Vol. 54, No. 1 (2010): 113-122

Zarkasyi, Muhammad Ridlo. "Membangun Budaya Akademik pada Perguruan Tinggi Pesantren.” Al Tijarah, Vol. 3, No. 2 (2017): 65-96 